\title{
Correspondence
}

\section{The long-stay patients and the community DEAR SIRS}

Until the mid-eighteenth century there was virtually no provision for the mentally ill. They, along with vagrants, were left in the community, often in dilapidated accommodation living rough as tramps or in the bridewells and doss houses of the day. Those in the community with a social conscience felt that this situation was to the detriment of the mentally ill, and the Vagrancy Act of 1744 required every Parish to look after their 'furiously and dangerously mad' in suitable accommodation.

The community then, as now, being somewhat dilatory in putting through such financially costly accommodation out of the then equivalent rates, Parliament realised that something more definite should be done.

The Asylum Act of 1808 was a permissive act that recommended every county to provide proper asylum for pauper lunatics. The county councils remained equally dilatory and this led to Lord Shaftesbury's second Asylum Act of 1845 which made provision of the county mental hospitals compulsory. This, at the time, was a great advance in the treatment of the mentally ill, or at least in their care.

There is currently a move to return the mentally ill into the community and to reduce the reliance on the old and often outdated county medical hospitals. Some States in America, and the Italian experiment, have shown the disasters that can occur when 'this policy is forced through against the advice of the more conservative elements who recognised that many of the chronically mentally sick do need asylum in the pure sense of the word! ${ }^{1}$

A number of articles have appeared in recent years examining the situation in which the long-term mentally ill find themselves as a result of the following through of the policy of community care. It has been recognised that a continuing need for in-patient care of some sort is likely to remain with us. Haslam, ${ }^{2}$ as far back as 1970 , noted the accumulation through the district general hospital of some 1 per 10,000 population per annum of long-stay that would require much longer term in-patient accommodation. In Bristol Measey and Smith $^{3}$ similarly noted that 106 patients had accumulated in the five years, and Le Gassicke ${ }^{4}$ noted similar figures in 1977 for St George's Hospital in Morpeth. Bewley et al, ${ }^{5}$ in his Tooting Bec study in 1981, noted an accumulation of some 80 patients in five years under the age of $\mathbf{6 5}$ and felt that a third of these were likely to be permanent admissions.

What has happened to those who have been discharged? Begun, ${ }^{6}$ speaking in Manhattan in 1981, mentioned that there were 60,000 vagrants in the city of New York and some 30,000 of these had a history of mental illness. All were in the community and it would seem that vagrants and the mentally ill were again being lumped together much as 200 years ago. Begun stated the unbelievable human misery which their special situation represents must be ascribed to having resulted from a fallacy too long subscribed to by the public health authorities who in a misdirected effort to protect freedom and civic rights have advocated the abolition of long-term institutional treatment in favour of the community based after-care when this latter is not a real option since the facilities are not there'. Kathleen Jones has written similarly about the situation in Italy. ${ }^{1}$

What of this country? Blackburn's article, ${ }^{7}$ based on the Middlesbrough experience, should provide an ominous warning to us all. He stated that beds in St. Luke's had dropped from a 1960 level of 550 to 310 in 1974 but by then not a single hostel place had been created. Of the 230 long-stay discharged virtually all remained dependent and there was no room for readmission in the district hospital. It would be no surprise to learn that they were living in dilapidated accommodation in bedsitters, in Salvation Army hostels, in derelict areas where no on else was prepared to go, and sleeping rough. Many had become recidivist offenders and landed in jail (bridewells?).

What a pity Lord Shaftesbury can't come back and give us a lecture.

\section{Clifton Hospital}

M. T. HASLAM

York

\section{REFERENCES}

'JONES, K. \& PoletTr, A. (1985) Understanding the Italian experience. British Journal of Psychiatry, 146, 341-347.

${ }^{2}$ HASLAM, M. T. (1970) District hospital psychiatry. The Practitioner, 204, February.

${ }^{3}$ MeAsey, L. G. \& SMath, H. (1973) Patterns of new chronicity in a mental hospital. British Journal of Psychiatry, 123, 349-351.

${ }^{4}$ LE GAssicke, J. (1977) The Accretion of Long-Stay Patients in a Mental Illness Hospital. St George's Hospital, Morpeth. Smith, Kline \& French Publication.

'Bewley, T. H., Bland, M., Mechen, D. \& Walch, E. (1981) 'New chronic' patients. British Medical Journal, 283, 1161-1164.

${ }^{6}$ Begun, M. S. (1981) Critical Issues for Psychiatry in the 1980s. Conference report of the WPA Regional Symposium held in New York.

'Blackburn, J. (1977) Problems in the Provision of Community Care. St Luke's Hospital, Middlesbrough. Smith Kline \& French Publication.

\section{Further observations on the Second AUTP Conference}

\section{DeAr Sirs}

Concerning Dr Graham Davies' personalised account of the AUTP Conference on Teaching Dynamic Psychotherapy (Bulletin, September 1985, 9, 174-176), we, both as participants in the Conference as a whole and more specifically members with Graham in the same small discussion 
group, feel that his account of the conference does less than justice to its constructive aspects and to the speakers who, alive to the complex issues, strove to present their own approach boldly to provoke discussion.

We were astonished to read, 'The conference was singularly without overt controversy until at one point ...' Our memory of the small group discussion was that of lively heated countering of the repeated assertion that the conference was riven by a polarity between psychoanalysis and scientific pragmatism.

The idea that psychoanalysis and scientific pragmatism are antithetical and compulsively locked in a mutually envious struggle, which is the basic assumption, is an antiquated one which need no longer be retained (even by some august figures who appear still to need to maintain the split to buttress their own identity). Will' $\mathrm{s}^{1.2}$ concepts of levels of generative mechanism backed by a philosophy of transcendental realism allow the mental mechanisms of the internal world to be open to scientific status as testable hypotheses and to rest separately but comfortably with the falsifiable hypotheses of the empirical realist set in the external world. The idea that both analysis and empiricism are necessarily unbalanced is false. The psychoanalyst can contain in a feminine way and create order by the scientific testing of his hypotheses via interpretation in a masculine way. The empirical realist needs feminine intuition to create hypothesis which he then studies with the masculine falsifiability trial. Certainly cross-fertilisation from empiricism to psychoanalysis and vice versa can occur but is not absolutely necessary for the growth of either.

In trying to understand the need of a basic assumption of a split between analysis and scientific pragmatism, we would like to take up the proffered but not fully worked out allusion to Oscar Wilde together with the misunderstanding of Dr Sandra Grant's comments on perversion and offer an interpretation of the dynamics involved. As MacDougall points out, ${ }^{3}$ the basis of perversion is the inability to internally hold on to the good penis in good intercourse. The result is that what was abolished internally returns from without, but in a persecutory fashion. There is then the compulsion to escape from the genital world of father's ordered universe into a world of chaos and hybridisation. ${ }^{4}$ The perversion thus rests on the disavowal of the legitimate source of knowledge introjected as a good object.

All this relates to our small group discussion about introjection of one's analyst or personal therapist, and the internal emptiness which the lack of such introjection may lead to. The position reached may be the tramp-like situation quoted from Dr Rosen's paper, where there is dependence on soup without proper acknowledgement of the source. This leads on to the further concern that introjection of one's source as an object leads to the creation of an internal ideology (religion). We would agree this is a potential difficulty. Rubens $\mathbf{5}^{\mathbf{3}}$ has pointed out that the introjection of the good object/person is necessary for growth in structure which in turn will allow the freedom from anxiety that Dr Steiner talks about. Although there is a danger of idealisation, the process can also lead, because of the reduction in anxiety, to an increased ability to think freely, which can lead then to the lysis of any idealisation. The trainee is then able to assume a freedom of hypothesis within the structure of acknowledgement of good sources.

Our overall view is that the account of the conference in its insistence upon the envious split actually spoiled the goodness that was there and our motive for writing lies in the anxiety that psychiatrists and trainees take this split to be a real and irradicable one. The subtitle is 'A Wilde Analysis of Hamlet'. The ending of the story of the Nightingale and the Rose is typical of Wilde's perversion. He could not, of course, ever allow good intercourse between the student and the professor's daughter but in his envy had to keep them forever apart.

Peter Whewell Charles Lund

Dryden Road Hospital

Gateshead, Tyne and Wear

REFERENCES

${ }^{1}$ WILL, D. (1980) Psychoanalysis as a human science. British Journal of Medical Psychology, 53, 201.

2_ (1983) Transcendental realism and the scientificity of psychoanalysis: A reply to criticism, British Journal of Medical Psychology, 56, 371-378.

${ }^{3}$ Macdougall, J. (1972) The primal scene and perversion. International Journal of Psycho-Analysis, 53, 371.

${ }^{4}$ Chasseguet-Smirgal, J. (1983) Perversion and the universal law. International Review of Psycho-Analysis, 10, 293.

${ }^{5}$ RuBENs, R. (1984) The meaning of structure in Fairbairn. International Review of Psycho-Analysis, 11, 429.

\section{DeAr Sirs}

I read Dr Davies' 'personal observations' of the Second AUTP Conference (Bulletin, September 1985, 9, 174-176) with great interest. In my view his treatment of his subject matter represents an approach based on what he himself labels the 'analytical stance'.

The sketches of the conference themselves demonstrate the 'perennial dilemma' of the social sciences between 'understanding' (Verstehen) and 'explanation' (Erklaren) and also the ever present ambiguity surrounding the meaning of 'facts' inferred by observers, participant or otherwise. Without intending to question the validity of $\mathrm{Dr}$ Davies' observations, I wish to express my belief that different observers could have given different descriptions of the events of the conference. Stating that Glyn Bennett was attacked is one possible inference. Another inference, and one based on a lower level of abstraction, would be to state that a number of individuals representing some contrasting theoretical (existential?) positions were expressing marked disagreements with Dr Bennett's views.

To further highlight this basic difficulty in establishing the 'facts' I turn to Dr Davies' judgement that Dr Steiner believes what he understands in terms of his theory to be 'literally true'. I wonder if the very same judgement may not be levelled against Dr Davies himself. Was his statement 'It was Bennett who was the perfect scapegoat for the 